\title{
Metastatic Small Cell Carcinoma
}

National Cancer Institute

\section{Source}

National Cancer Institute. Metastatic Small Cell Carcinoma. NCI Thesaurus. Code

C158911.

A small cell carcinoma that has metastasized from its original site of growth to another anatomic site. 